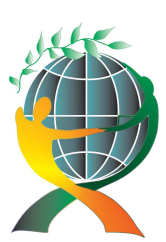

\author{
(online) $=$ ISSN $2285-3642$ \\ ISSN-L = $2285-3642$ \\ Journal of Economic Development, Environment and People \\ Volume 6, Issue 2, 2017
}

URL: http://iedep.spiruharet.ro

e-mail: office jedep@spiruharet.ro

\title{
Knowledge management as a strategic business resource
}

\author{
Adam Grzegorczyk, Eugen Ghiorghiță \\ University of Promotion in Warsaw \\ Spiru Haret University Bucharest
}

\begin{abstract}
The development of a knowledge-based economy means that today's businesses face many of the new challenges of adapting to the changing environment. Since the early 1990s, knowledge management became not only an academic discipline, but more than that, an effective way to assure the continuous improvement of the organization. Seeking advantages that make them more competitive led companies to focus on the complex philosophy of intellectual capital and its connected concepts: human capital, structural capital, organizational capital, intellectual property, and last but not least, relational capital. The present article puts forward a short insight into the complexity of the ever changing and evolving system of knowledge management various concepts.
\end{abstract}

Keywords: knowledge management, intangible assets, intellectual capital, intellectual property, structural capital, customer capital

JEL Codes: D83; E22, J24

\section{Introduction}

Intellectual property is closely related to the process of acquiring, developing and using knowledge in the enterprise. By analyzing the definition of intellectual property one can conclude that it is the result of human work, skills, competences and attitudes such as creativity, ingenuity, inventiveness. It arises as a result of human creativity and is the fruit of his mental work.

The key factor to success in a business is human. He is the subject of all action. He creates, builds, and performs tasks in an enterprise using his knowledge.

Knowledge is closely linked to the human factor, which is defined in the organization as human capital. On knowledge is based the whole of human civilization. As a man is a thinking being, he has the ability to accumulate process and transmit knowledge.

Knowledge it was a human attribute since the origin of mankind. Almost every moment of his life a person has to deal with it and participate in its creation, flow and exploitation.

By analyzing the genesis of knowledge in an organization, one can conclude that knowledge has always been used in an enterprise. As a matter of fact, for hundreds of years the owners of the organization have relayed their knowledge to their successors. The master communicating the knowledge to the journeyman, and the journeyman to the student, were managing the resources of knowledge. 


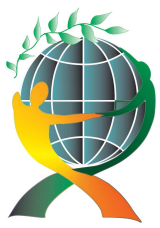

\author{
(online) $=$ ISSN $2285-3642$ \\ ISSN-L = $2285-3642$ \\ Journal of Economic Development, Environment and People \\ Volume 6, Issue 2, 2017 \\ URL: http://iedep.spiruharet.ro \\ e-mail: office jedep@spiruharet.ro
}

The first scholar who appreciated the importance of knowledge in the economy was Peter Drucker. He introduced the terms knowledge work and knowledge worker. Drucker also deemed that the era of knowledge society has started to reign, in which knowledge and knowledge worker are the overriding resources, and resources previously considered as traditional, such as capital, land and work, are losing their importance.

Peter Druker recognizes the important role of knowledge, pointing out that "knowledge has become a major economic asset and the most important and perhaps the only source of competitive advantage". In addition to such resources as land, work and capital, knowledge has grown over the last few years to become a key resource for organizations. Many scientific analyzes, as well as practical experience, show that it has become a strategic resource for the organization. Today, we speak of the capital of knowledge that contributes to the growth and strategic market success of the enterprise [1].

The business world has come to realize the establishment of a new age, whose main wealth is knowledge, and a new "knowledge workers" elite whose capital is all in the head. Each company has its own individual and competent knowledge, located in the heads of employees.

No man has enough knowledge to build by himself a modern computer or plane. It requires versatile knowledge in various fields, which transcends human capabilities as individuals. The organizations, however, can transcend the capabilities of man as an individual, with the knowledge of many people associated therein, so-called human capital.

The effect of human capital is innovation. Innovation is one of the important elements of building competitive advantage among enterprises operating in the economy based on knowledge. Hence, it is increasingly necessary to focus the organization's attention on the process of creating knowledge, since modern conditions require knowledge to be acquired by the company at a certain place and time so that it can operate effectively and be competitive on the market. [2].

\title{
1. THE INTELLECTUAL PROPERTY IN ENTERPRISE
}

Intellectual property is closely linked to a knowledge-based economy, inventiveness and innovation are one of the most valuable assets of a company.

The development of a knowledge-based economy means that today's businesses face many of the new challenges of adapting to the changing environment. Waldemar Walczak includes, among others, the acquisition of knowledge and intellectual capital as a source of competitive advantage, development of entrepreneurship, implementation of new technological solutions, creation of innovative undertakings. He believes that the intellectual property is a specific type of intangible asset of an enterprise with a special legal status, requiring in many cases the specific financial outlays associated with their preservation and protection. It is a component of organizational capital, which is one of the components that creates a comprehensive image of the organization's intellectual capital. Intellectual capital is built on the use of valuable knowledge and unique intangible assets to generate future benefits by which a company can gain a competitive advantage by contributing significantly to building market value.[3]

\section{THE CONCEPT OF INTELLECTUAL CAPITAL}

The nature of intellectual capital is not yet fully understood and described, so it is difficult to grasp it with clear terms and unambiguous terms. On the other hand, the struggles of the representatives of the 


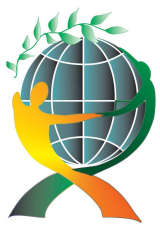

\author{
(online) $=$ ISSN $2285-3642$ \\ ISSN-L = $2285-3642$ \\ Journal of Economic Development, Environment and People \\ Volume 6, Issue 2, 2017 \\ URL: $\underline{\text { http://iedep.spiruharet.ro }}$ \\ e-mail: office jedep@spiruharet.ro
}

interested circles to find a uniform definition resulted in numerous descriptions, but none of them has been recognized so far and was therefore not universally accepted.[4].

The attempt to identify the essence of intellectual capital lies in the difference between the market value and the accounting value of an enterprise. However, until the difference was small, it was not considered. As the market value of the company began to decide primarily on intangible assets, the role of intellectual capital increased [5].

Skandia is a precursor in the field of intellectual capital research in the insurance sector, founded 150 years ago in Sweden. Therefore, the most widespread definition of intellectual capital is the definition that is the result of research conducted in this enterprise. These studies have allowed the definition of intellectual capital as the sum of human capital and structural capital. In the early 1990s, a reporting system was developed to show the state of the company's intellectual values. In 1995, Skandia released the world's first public annual report on intellectual capital, which is an addition to the financial report. This company was the first to introduce the position of director of intellectual capital in its organizational structure. Skinner AFS's intellectual capital director, Leif Edvinsson, described intellectual capital as "knowledge that can be transformed into value."[6].

Collectively defined definition by Leif Edvinsson and Michael Malone identifies intellectual capital as having the knowledge, experience, organizational technology, customer relationships, and professional skills that allow a company to gain competitive advantage. These authors use interchangeably terms such as knowledge capital, non-financial assets, intangible assets, hidden assets, invisible assets, and means of achieving the goal.[7].

It is worth to mention similar definitions developed by people working with Skandia or inspired by the Edvinson idea. Tom Stewart defines this concept as "the sum of everything everyone knows in the organization, which gives it a competitive advantage." By presenting intellectual capital as intellectual material, i.e. knowledge, information, intellectual property and experience that can be used to create wealth, Stewart shows the components of intellectual capital: patents, processes, managerial skills, technology, consumer and supplier information, and experience[8].

Patrick Sullivan defines intellectual capital saying: "it is all it comes out with when you finish working out the door of your business. It is also the sum of knowledge and everything that can be transformed into real business profits". [9]

Defining intellectual capital, Klark E Sveiby closely ties it with the notion of knowledge management. Claiming that "intellectual capital and knowledge management are twin concepts - two trunks of the same tree", the author points out that the main difference is the degree of dynamics of both concepts, namely, intellectual capital is a static concept and it is necessary to use a verb for intellectual capital activities. On the other hand, knowledge management is an active term and can be defined as the art of creating value from the intangible assets that an organization has. [10].

In turn, Anna Brooking describes intellectual capital as a complex concept, that incorporates components such as market assets, human factor assets, infrastructure assets, and intellectual property. The author presents the view that "intellectual capital is the result of the interaction of several subprocesses, e.g. 


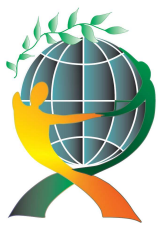

\author{
(online) $=$ ISSN $2285-3642$ \\ ISSN-L = $2285-3642$ \\ Journal of Economic Development, Environment and People \\ Volume 6, Issue 2, 2017 \\ URL: $\underline{\text { http://iedep.spiruharet.ro }}$ \\ e-mail: office jedep@spiruharet.ro
}

the formulation of market strategy, knowledge management, selection of appropriate instruments for organization and management of intellectual property". [11]

According to the definition given by Goran Roos and Janne Roos the intellectual capital is "the sum of hidden assets of a business not included in its balance sheet, but including both what's inside the employees and what's left after they leave." [12]

Gordon Petrash from Dow Chemical describes intellectual capital as "knowledge that has the potential to transform into value"[13].

Recently, the OECD definition of intellectual capital proposed by the Organization for Economic Cooperation and Development is quite often used. It describes intellectual capital as "the economic value of two categories of intangible assets of an enterprise: organizational (structural) capital and human capital". [14]

In his book, Knowledge Management in Enterprise, Kazimierz Perechuda finds that the definition of intellectual capital is also defined as the difference between the market value of an enterprise and the cost of exchanging its assets, which, according to the author, means the combination of intangible assets that allow a company to operate and prosper, because they have been formalized, captured, forced to act, and are constantly being checked to create a higher value proposition for customers and stakeholders. The author, looking for a relationship between knowledge and intellectual capital, appeals to the definition of Karl Wiig, in which intellectual capital is defined as: knowledge, practical experience, technology, good customer relations and all the skills that enable the company to gain competitive advantage. Perechuda also draws attention to Mariusz Strojny's definition in which intellectual capital "consists of intellectual property, extending from acquiring new knowledge (learning) through inventions to creating valuable relationships with others."[15]

Kazimierz Perechuda also quotes the views of Mariusz Bratnicki and Jan Strużyna, stating that the total value of an enterprise consists of material capital, that is, material, financial and intellectual capital. These authors describe intellectual capital as "the sum of knowledge held by the people who form the corporate community and the practical transformation of that knowledge into the values of the enterprise. It encompasses all the irrelevant elements that shape the difference between the total value of an enterprise and its financial value". [16]

Agnieszka Sopińska has the vision that intellectual capital creates non-financial "invisible" assets of an enterprise, usually not recognized in balance sheet reporting, as a way to reach future goals as enterprise knowledge. Knowledge, experience, organizational technology, customer relationships and professional skills indicate that they cover both the minds of the members of the organization and what remains of the organization when they leave. In addition, it is important to point out the value of the company, its organizational culture and its philosophy of action (so-called human capital), as well as everything that supports you, i.e. employee productivity, such as computer hardware, databases, organizational structures, patents, and trademarks. (So-called structural capital) [17]

Bogusław Kaczmarek and Waldemar Walczak in the book Knowledge Management in Contemporary Enterprises cite the view of Grzegorz Urbanek, who notes that "intellectual capital is an invisible resource that creates visible effects. Intellectual capital is knowledge in itself and the result of its transformation into intangible assets". [18] 


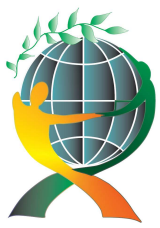

\author{
(online) $=$ ISSN $2285-3642$ \\ ISSN-L = $2285-3642$ \\ Journal of Economic Development, Environment and People \\ Volume 6, Issue 2, 2017 \\ URL: http://iedep.spiruharet.ro \\ e-mail: office jedep@spiruharet.ro
}

Based on the numerous definitions found in dedicated literature, Agnieszka Sopińska, in her book Knowledge as a Strategic Resource of Enterprise, has tried to formulate common features characterizing the essence of intellectual capital. By specifying that it consists of different categories, it is knowledge-based and bridges the gap between market value and accounting, encompassing all the irrational elements that make up the difference between the total value of an enterprise and its financial value. Proper use of it provides the company the basis for gaining competitive advantage on the market and managing it improves the value of the company. [19]

\title{
2.1. DIFFERENCES IN PERCEIVING THE INTELLECTUAL CAPITAL
}

In economic practice as well as in theoretical studies in this field, the concept of intellectual capital is often used interchangeably with the terms "knowledge capital", "intellectual property", "intangible assets", "intangible assets", "intellectual assets". [20]

Agnieszka Sopińska points out that "intellectual property" and "knowledge capital" are not synonymous with the term "intellectual capital." The author explains the conceptual scope of these terms by pointing out that the notion of intellectual property includes the ownership of patents, trademarks, copyright, and is therefore the result (resultant) of transforming the knowledge resources in the organization. The concept of knowledge capital includes the knowledge held by the organization without the effects of their transformation, while intellectual capital is both knowledge acquired as a resource and the result of transforming this knowledge into the form of intellectual property. [21]

According to Agnieszka Szczygielska, intellectual capital and intangible assets are very similar concepts, but intellectual capital takes into account and treats intangible assets from the point of view and on the base of knowledge and its management. At the same time, the author points out that capital comes from resources, is closely linked to them. [22]

Bogusław Kaczmarek and Waldemar Walczak, while analyzing the conceptual scope of intangible assets, argue that this is a concept presented in broad terms and means "all non-physical elements that have no physical form but are capable of generating future benefits for the enterprise." The authors point out that the term "intangible resources", considered broadly, constitutes the knowledge resources of human capital, which cannot be considered as a separate property of an enterprise, while the "intangible assets" are the property of an organization.

Kaczmarek and Walczak indicate that intangible assets and intellectual property terms are treated as ambiguous terms. According to the authors, the term "intangible" refers to non-physical factors, and the term "intellectual" refers to human factors. These authors, by defining the term "intangible assets", indicate that "it includes non-physical or financial factors that are owned by the business that will be of benefit to it in the future." By analyzing the concept of "intellectual assets", Kaczmarek and Walczak recall the view of Grzegorz Urbanek, who believes that they can be defined as "knowledge-based, open source of the future benefits of the company." He then adds that "the concept of intangible assets should not be identified with the concept of intellectual assets, because not all intangible assets are intellectual, so not all are part of intellectual capital, but when intellectual assets are protected by law they are intellectual property." [23] 


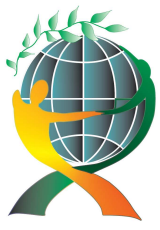

\author{
(online) $=$ ISSN $2285-3642$ \\ ISSN-L = $2285-3642$ \\ Journal of Economic Development, Environment and People \\ Volume 6, Issue 2, 2017 \\ URL: http://iedep.spiruharet.ro \\ e-mail: office jedep@spiruharet.ro
}

According to Kazimierz Perechuda, intellectual assets are those knowledge-based assets that are considered property of the company and which in the future will be the source of benefit to the enterprise. [24]

This heterogeneous terminology, among other things, has made the concept of intellectual capital still unclearly defined. The variety of definitions and ambiguity in the description of intellectual capital causes the ambiguity of the categorization of its components. [25]

\title{
2.2.1. COMPONENTS OF THE INTELLECTUAL CAPITAL
}

By analyzing the quoted definitions of intellectual capital, it can be seen that, due to the broad scope of this term, different definitions are used for its description. The general significance of these definitions do not make much difference, but to be able to manage the intellectual capital, protect and measure it, it is important to identify the range of assets that will be considered as intangible assets. It is therefore necessary to determine what is covered by this concept, i.e. what categories and constituents it covers. Also, there is no uniqueness in the literature in this field, and different authors propose different approaches.

Today, several leading concepts can be extracted. By analyzing them, it can be seen that although each author emphasizes the role of other components, all classification systems make a fairly clear distinction between: human capital, structural capital, and relational capital called "customer capital". It should be added that the original Skandia model assumed two forms of intellectual capital: human capital and structural capital. [26] Nowadays, Skandia's structured capital is further subdivided into internal and external structural capital-relational, which is defined by Skandia as capital in the form of "customers". [27]

It is worth emphasizing here that the classification proposed by Leif Edvinsson and Michael Malone in 1997 was a source of inspiration for many researchers and strongly influenced the future shape of the components of this area, as the various classifications of intellectual capital appearing in the literature are modifications proposed by these authors of the division. [28]

\subsubsection{HUMAN CAPITAL}

First, from the specified areas, human capital consists of: qualifications, knowledge, experience, skills, competences and intellectual and interpersonal skills of all employees and managers of the organization. This capital also includes people's attitudes and behaviours such as honesty, loyalty, commitment to work, employee motivation to share knowledge and information, pursuit of goals, focus on results, creativity, openness to innovation. [29]

As noted by Walczak, these attitudes are not only shaped by internal motives and their own system of values but are strongly influenced by the power of organizational culture. [30]

In the Scandinavian model, human capital is understood as capital "in an inseparable way integrated with man, his knowledge, experience, presence and possibilities of action in the enterprise". [31]

By analyzing the conceptual term human capital, Kazimierz Perechuda perceives it as "collective competence of the company to extract the best solutions from the knowledge of its employees". [32] 


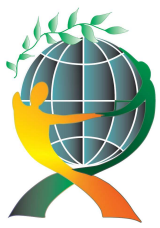

\author{
(online) $=$ ISSN $2285-3642$ \\ ISSN-L = $2285-3642$ \\ Journal of Economic Development, Environment and People \\ Volume 6, Issue 2, 2017
}

URL: http://iedep.spiruharet.ro

e-mail: office jedep@spiruharet.ro

It is worth stressing that this is a very specific type of capital, as it is the most important and, at the same time, the least sustainable category of intellectual capital. It is not owned by the organization, it can only be leased to it. Leaving of one of the employees means losing some skills, experience, and specific mechanisms of action, informal relationships with customers, suppliers, and other employees. As a result, the organization becomes poorer about its abilities, experience, skills, or some informal relationships that the employee has created with the other employees, which were translated into the efficiency of the organization's functioning. [33]

\title{
2.2.3. THE STRUCTURAL CAPITAL
}

Structural capital is "the result of targeted human actions." [34] It is the property of an organization and therefore the organization is free to dispose of it, often making it an object of trading. [35] It is created by: technologies, methods and processes, or so-called organizational knowledge, which allow the company to function. In addition, this capital includes organizational culture, organization history, risk assessment methodology, management methods, databases containing market or customer information, communication systems, computer systems, patents, conception, models, business secrets, copyright, design laws, trademarks and service marks, enterprise innovation, inventions, organizational learning, processes of strategy formation. [36]

Figure 1 Components of enterprise value

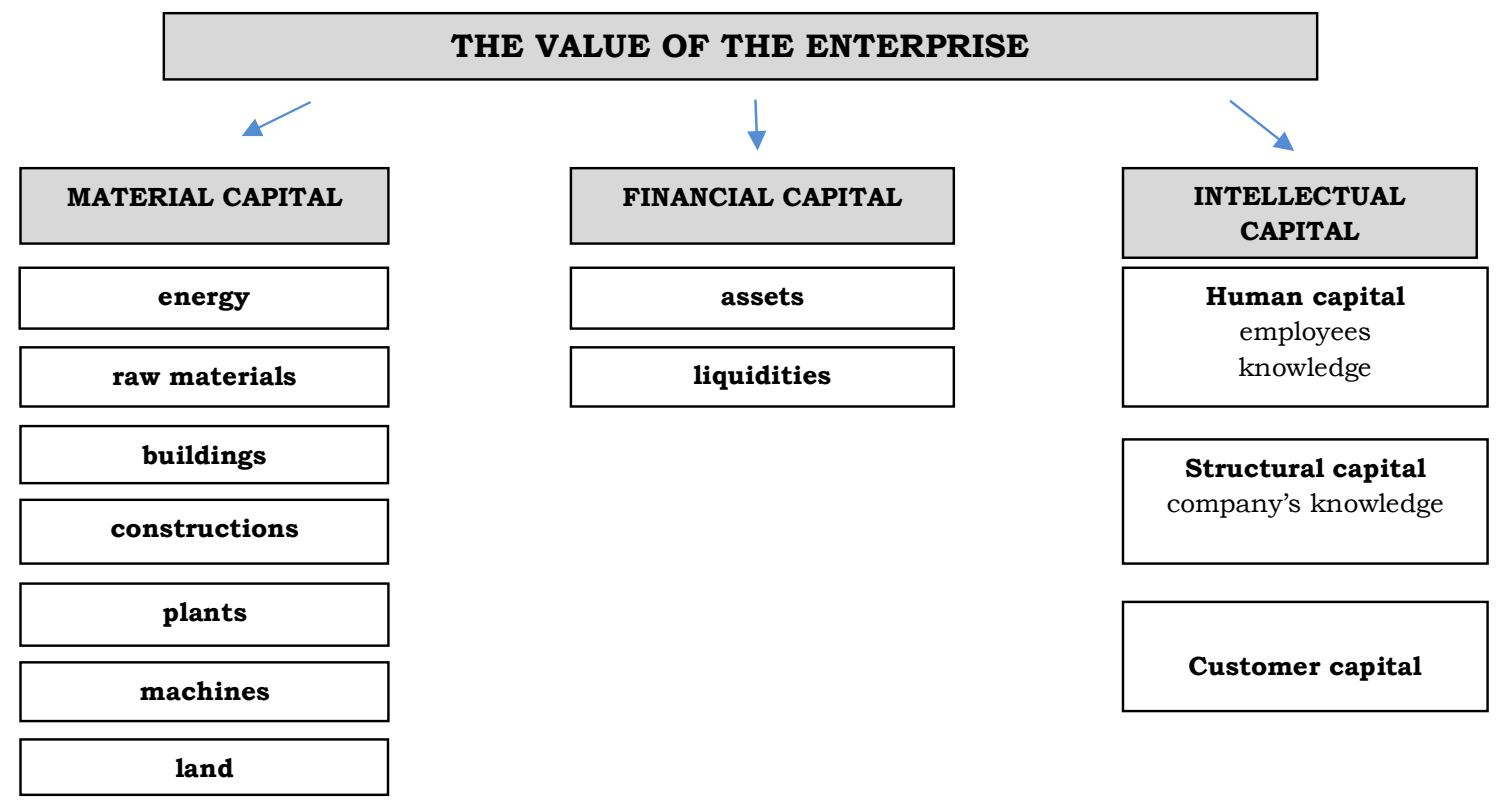

Source: Own (Adam Grzegorczyk) elaboration based on: W Kotarba, Ochrona własności intelektualnej, [Protection of the intellectual property] Oficyna wydawnicza Politechniki Warszawskiej, Warszawa 2012, p. 110 


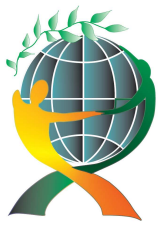

\author{
(online) $=$ ISSN $2285-3642$ \\ ISSN-L = $2285-3642$ \\ Journal of Economic Development, Environment and People \\ Volume 6, Issue 2, 2017 \\ URL: http://iedep.spiruharet.ro \\ e-mail: office jedep@spiruharet.ro
}

Rafat Haffer notes that structured capital consists of three components: organizational capital, innovation capital and process capital. Organizational capital consists of management processes, investments in systems and tools, organizational culture and a philosophy that fosters the flow of knowledge both within the organization and outside, databases, patents, trademarks and copyrights. [37] Skandia's organizational capital is primarily the investment of a strategic enterprise in systems and tools that accelerate the flow of knowledge within the enterprise and its surroundings. [38]

Innovation capital is the ability of an enterprise to renew itself through innovation in the form of protected intellectual property rights, commercial rights and other intangible assets such as the theory that the company is operating, talents, abilities and competences, allowing the company to respond quickly to economic progress to create and market new products and services. [39]

Process capital is a type of practical knowledge for continuous value creation - including work processes, organizational processes, work procedures, techniques, and employee programs that enhance organizational effectiveness. [40]

\title{
2.2.3. RELATIONAL CAPITAL - COSTUMER CAPITAL
}

Relational capital is the customer capital often found in the literature as the market capital. This includes the business potential associated with the intangible market asset. It concerns the relationship with customers. It is generally about connections and relations with clients, mainly those based on loyalty, price sensitivity, or the period of cooperation with the customer. It consists of: trademarks, various contracts and agreements, e.g.: licensing, concession, marketing strategies, including: development of product quality, pricing strategies, distribution channels, the means of promotion, reputation and corporate image, formal and informal relationships with suppliers, with shareholders, partners or other stakeholders in the company environment. [41]

\subsubsection{RELATIONSHIP OF THE INDIVIDUAL ELEMENTS OF THE INTELLECTUAL CAPITAL}

All elements of intellectual capital are interconnected and interrelated, so they should not be separated. [42] Separation of human capital into structural and market capital makes it impossible to create an enterprise's intellectual capital. Its strength is due to the links between the individual elements.

People create an image of the organization they work with and their attitudes and behaviour build relationships with the clients and influence them. The acquired customer capital contributes to the strengthening of market capital, and consequently directly affects the acquisition of new customer groups. [43]

Human capital needs structural capital. Also, market capitalization without the rest of the elements will not contribute to intellectual capital growth, since even the best product brand alone will not provide the company with success. If employees cease to develop their skills, the product offered can quickly become obsolete technologically. [44]

\section{Conclusions}

Intellectual property is an important part of an organization's intellectual capital, which together with the material capital and financial capital decides the market value of the organization. [45] 


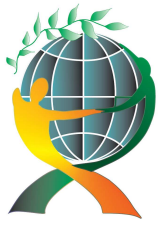

\author{
(online) $=$ ISSN $2285-3642$ \\ ISSN-L = $2285-3642$ \\ Journal of Economic Development, Environment and People \\ Volume 6, Issue 2, 2017 \\ URL: http://iedep.spiruharet.ro \\ e-mail: office jedep@spiruharet.ro
}

Nowadays, the market value of an enterprise increasingly exceeds its book value. This difference is due to the presence of intellectual capital which includes all non-material elements. Intellectual capital, in addition to knowledge, includes, but is not limited to, corporate image, information systems and administrative procedures, process efficiency, experience, staff potential, know-how, patents, organizational culture, creative atmosphere, customer relations and other external factors. The shape of the above elements of intellectual capital is often directly or indirectly influenced by knowledge. [47]

\title{
References
}

[1] A. Błaszczuk, J. Brdulak, M. Guzik, A. Pawlaczuk, Zarzq̨dzanie wiedzq w polskich przedsiębiorstwach [Knowledge Management in Polish Companies], Szkoła Główna Handlowa, Warszawa 2003 p. 13.

[2] A. Kowalczyk, B. Nogalski, Zarzq̨dzanie wiedzq: koncepcja i narzędzia, Dyfin, Warszawa 2007, p.24-25, A. KnapStefaniuk, Ludzie-bezcenny kapitał, „Zarządzanie Zmianami”, 2004, nr 1 p. 23.

[3] Walczak W., „Własność intelektualna - cenne niematerialne aktywa organizacji”, E-mentor nr. 2 (39)/2011.

[4] A. Sopińska, Wiedza jako strategiczny zasób przedsiębiorstwa. Analiza i pomiar kapitału intelektualnego przedsiębiorstwa SGH, Warszawa 2008, p. 101-104.

[5] P. Wachowiak (red.), Pomiar kapitału intelektualnego przedsiębiorstwa, Szkoła Główna Handlowa, Warszawa 2005, p. 43-44.

[6] Ibidem, p. 43-44.

[7] E. Skrzypek (red.), Zarzqdzanie kapitałem ludzkim w gospodarce opartej na wiedzy, Instytut Wiedzy i Innowacji, Warszawa 2009, p. 101.

[8] A. Błaszczuk [et al.], op. cit., p. 73.

[9] Ibidem.

[10] A. Sopińska, op. cit., p. 102; K. Perechuda (red.), Zarzq̨dzanie wiedzq w przedsiębiorstwie, PWN, Warszawa 2005, p. 132.

[11] A. Sopińska, op. cit., p. 102; K. Perechuda (red.), op. cit., p. 133.

[12] A. Sopińska, op. cit., p. 101; E. Skrzypek (red.), op. cit., p. 184.

[13] A. Sopińska, op. cit., p. 102; K. Perechuda (red.), op. cit., p. 132.

[14] K. Perechuda (red.), op. cit., p. 133.

[15] Ibidem, p. 130, 132.

[16] Ibidem, p. 133.

[17] P. Wachowiak (red.), op. cit., p. 43-44.

[18] B. Kaczmarek, W. Walczak, Zarzqqdzanie wiedzq we współczesnych przedsiębiorstwach, Uniwersytet Łódzki, Łódź 2009 p. 233.

[19] A. Sopińska, op. cit., p. 103.

[20] K. Perechuda (red.), op. cit., p. 134; A. Sopińska, op. cit., p 103-104.

[21] A. Sopińska, op. cit., p. 103-104. 


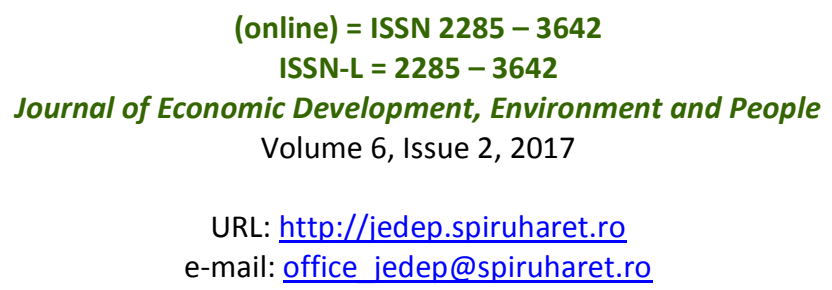

[22] A. Szczygielska, Kapitał intelektualny w gospodarce opartej na wiedzy, Uniwersytet Ekonomiczny we Wrocławiu, Wrocław 200., p. 13.

[23] B. Kaczmarek, W. Walczak, op. cit., p. 243.

[24] K. Perechuda (red.), op. cit., p. 134.

[25] A. Sopińska, op. cit., p. 104.

[26] K. Perechuda (red.), op. cit., p. 136; M. Juchnowicz (red.), Elastyczne zarzqdzanie kapitałem ludzkim w organizacji wiedzy; Difin, Warszawa 2007, p. 31. S. Kasiewicz, W. Rogowski, M. Kicińska, Kapitał intelektualny: spojrzenie z perspektywy interesariuszy, Oficyna Ekonomiczna, Kraków 2006 [et al.], p. 82.

[27] P. Wachowiak (red.), op. cit., p. 45; K. Leja (red.), Zarzqdzanie wiedzq:: wybrane problemy, Politechnika Gdańska, Gdańsk 2006, p. 103; K. Perechuda (red.), op. cit., p. 136.

[28] D. Jemielniak, A. K. Koźmiński (red.), op. cit., p 277-278.

[29] B. Kaczmarek, W. Walczak, op. cit., p. 250; S. Kasiewicz [et al.], op. cit., p 82-83; K. Perechuda (red.), op. cit., p. 136.

[30] B. Kaczmarek, W. Walczak, op. cit., p. 250.

[31] K. Leja (red.), op. cit., p. 103.

[32] K. Perechuda (red.), op. cit., p. 136.

[33] S. Kasiewicz [et al.], op. cit., p 82-83; P. Wachowiak, op. cit., p. 45; K. Perechuda (red.), op. cit., p. 136-137.

[34] K. Leja (red.), op. cit., p. 103.

[35] P. Wachowiak (red.), op. cit.

[36] K. Perechuda (red.), op. cit., p. 136.

[37] M.J. Stankiewicz (red.), Zarzqdzanie wiedzq jako kluczowy czynnik międzynarodowej konkurencyjności przedsiębiorstwa, Towarzystwo Naukowe Organizacji i Kierownictwa „Dom Organizatora” Toruń 2006, p. 151.

[38] K. Leja (red.), op. cit., P. Wachowiak (red.), op. cit.

[39] P. Wachowiak (red.), op. cit.; K. Leja (red.), op. cit.; A. Błaszczuk [et al.], op. cit., p 74-75.

[40] Ibidem.

[41] Ibidem.

[42] K. Perechuda (red.), op. cit.

[43] B. Kaczmarek, W. Walczak, op. cit., p. 2

[44] P. Wachowiak (red.), op. cit. p. 123

[45] W. Kotarba, Ochrona własności intelektualnej, Oficyna Wydawnicza Politechniki Warszawskiej, Warszawa 2012, p.110

[46] M. Nycz, M.L. Owoc, (red.), Pozyskiwanie wiedzy i zarzq̨dzanie wiedzq, Akademia Ekonomiczna im. Oskara Langego we Wrocławiu, Wrocław 2004, p. 67.. 